\title{
INFLUENCE OF JOB EVALUATION ON TEACHERS' PERFORMANCE IN PUBLIC SECONDARY SCHOOLS IN NAKURU EAST SUB-COUNTY, KENYA.
}

\author{
Antony Thiong'o Kinyanjui
}

School of Entreprenuership, Procurement \& Management

Jomo Kenyatta University of Agriculture and Technology, Kenya

Josphat W. Kwasira

School of Entreprenuership, Procurement \& Management

Jomo Kenyatta University of Agriculture and Technology, Kenya

\begin{abstract}
Job evaluation is discussed relative to performance evaluation. That is, presumptively, job evaluation impacts on both employee and organizational performance. Hitherto, teachers' performance is pegged on the academic performance of students as reflected in the results of the national examinations. In spite of the fact that performance contracts could facilitate objective evaluation and appraisal, teachers have been reluctant to sign them. The current metric of evaluating the teacher's performance is questionable given that students' performance is not entirely attributed to teachers' efforts. The study aimed to assess the effect of job evaluation on performance of teachers in public secondary schools in Nakuru East Sub-County. It was guided by one specific objective which sought to examine the effect of methods of job evaluation on performance of teachers in the aforesaid sub-county. Descriptive research design was the blueprint that guided the entire study. The target population constituted 283 teachers working with the 11 public secondary schools in Nakuru East Sub-County. A sample of 75 respondents participated in the study. Stratified random sampling method was adopted to draw sampled respondents from the target population. A structured questionnaire was used to collect primary data from the sampled respondents. The questionnaire was pilot tested before its administration in the main study in order to facilitate determination of both its reliability and validity. The collected data was analyzed using both descriptive and inferential statistics. Data analysis was in form of frequency and percentage distributions, means and standard deviations and Pearson's correlation coefficient. The study findings were presented in form of tables that captured summary statistics.
\end{abstract}

Keywords: Job evaluation, Teachers' Performance, Public Secondary Schools, Nakuru East Sub-County.

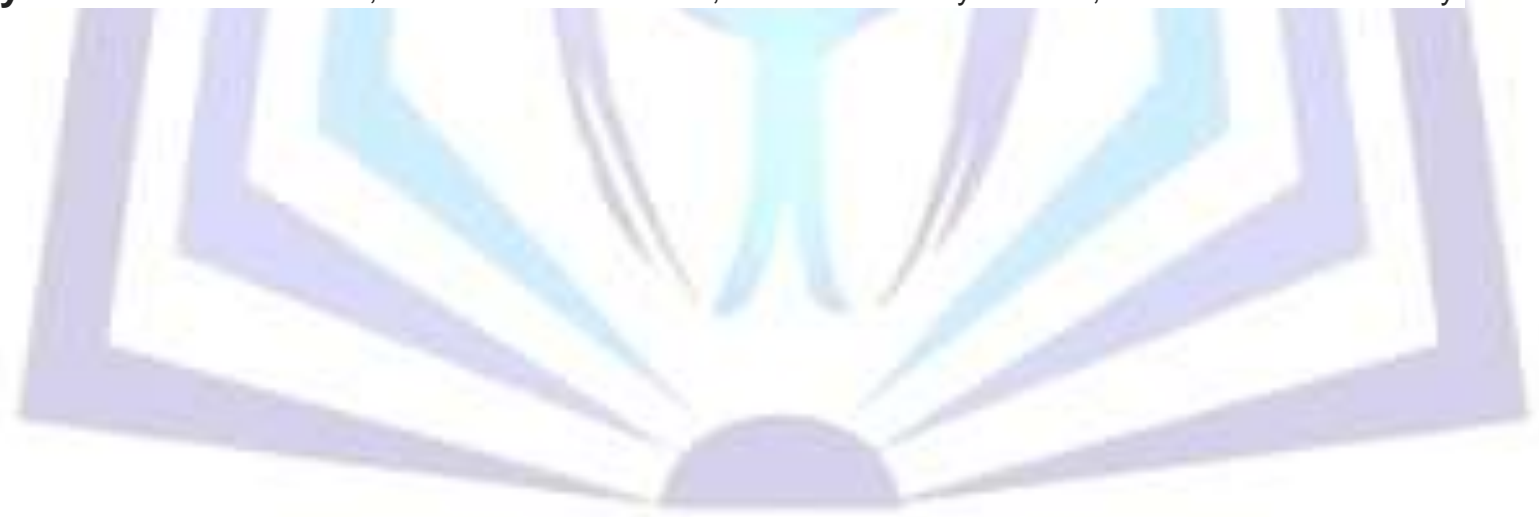

\section{Council for Innovative Research}

Peer Review Research Publishing System

\section{Journal: International Journal Of Management \& Information Technology}

Vol . 10, No 9

editorsijmit@gmail.com

www.ijmit.com 


\subsection{Introduction}

The role played by the teachers in the academic performance of students cannot be underestimated. The teachers' performance is hypothesized to be influenced by how their job is evaluated. As such, the theme of job evaluation in the context of teachers' performance specifically in public secondary schools is important. This chapter delves into the general background of job evaluation and teachers' performance, the driving force behind conducting this study, the objectives and hypotheses alongside the scope of the study.

\subsubsection{Job Evaluation}

Job evaluationwhich is discussed in the same light as performance evaluation is described as the judgmental evaluation of a job holder' traits, behaviour and outcomes. It is argued that the superior's evaluative style may impact on subordinate's job performance (Chong, 2004). Employee performance is very important to every organization public or private, profitmaking or non-profit making. Enhancing the employee performance demands organizations to come up with practices of effective management of employees. Such practices touch on a number of issues which include job evaluation (Kirkpatrick, 2006). It is noted that when employees perform their jobs excellently, then they are bound to conduct their duties efficiently and effectively in order to meet the set organizational objectives (Baldwin, 2008). This concurs with Sousa et al.'s (2005) assertion that employee performance regardless of the organization is reflected in the effectiveness and efficiency with which goals and objectives are achieved.

While looking into the measures and the rationalization of organizations, Townley, Cooper and Oakes (2003) noted that the changes that were introduced in Alberta on the same were rather dramatic. The authors exemplified that in 1993-1994, all State departments were expected to produce three-year business plans highlighting their objectives and goals alongside a series of indicators and measures to allow an evaluation for their success. The subjective evaluation of performance is discouraged in order to enhance the objectivity of the results (Townley et al., 2003). Dessler (2003) further asserted that teacher appraisals are a metric that is employed to evaluate their performance against pre-set standards. This is also described as a merit rating particularly when the same is used to award salary or wage increment to teachers according to their performance.

In an empirical investigation of the impact of organizational factors on the perceived job performance conducted in Sri Lanka, It is noted that performance evaluation is one of the organizational factors that could possibly impact on the perceived job performance. Alongside organizational structure, evaluation of performance was found to strongly influence perceived job performance. In an analysis of effectiveness of self appraisal in Botswana, it is averred that employees react positively to an appraisal system that addresses their needs and one that allows them to state their position when factors on which they are being evaluated are related to their jobs. They also embrace an appraisal process whose evaluation objectives and plans are openly discussed (Malongwe, 2005). The scholar laments that school heads and teachers at times fail to agree on what constitute an effective appraisal. It is observed that teachers advocate for an evaluation mechanism that is interactive, inclusive and one that stresses on values, teamwork and employees' job roles. According to Monyatsi, Steyn and Kamper (2006) teachers' appraisal policy in Botswana emphasizes that the entire process ought to be professional, non-threatening and constructive.

\subsubsection{Teachers' Performance}

A study was conducted on the dynamics and trends of employment in Kenya (Omolo, 2010). It is reported that, over the years, there has been many policy blueprints on measures of creating employment in the country. More so, it has been noted that a lot of focus has been on employment policy formulation and legislation in Kenya with little and non-matching emphasis on policy implementation, monitoring, evaluation, and learning. Omolo further underscores the importance of Kenya putting greater emphasis on implementation of the identified employment promotion policies and consequently develop a framework for monitoring, evaluation and learning that incorporates both state and non-state actors. A study on the experiences of teachers' appraisal practices in public secondary schools in Nairobi (Odhiambo, 2003) revealed that teachers perceived the performance appraisal negatively. In the same breadth, Richu's (2007) study on perceptions of teachers on performance appraisal in public secondary schools in Nakuru district indicated that teachers viewed performance appraisal negatively.

Moreover, Asiago and Gathii (2014) analyzed the teachers' perceptions of performance appraisal practices in public secondary schools in Limuru District, Kenya. They acknowledged that the evaluation of employees' present and past performance against standards set by respective organizations is important to the achievement of the organizational goals. Appraisal of teachers which encapsulates their evaluation is not an easy task in the context of public secondary schools. This assertion is affirmed by Asiago and Gathii where they noted that most school heads had no training on how to appraise teachers. With the acknowledgement that appraisal of teachers is vital in their development, it is recommended that the Ministry of Education ought to train school heads on how to appraise teachers in their respective secondary schools.

It is complained that the Kenyan education system tends to overlook the affective domain of the curriculum and instead acknowledges the cognitive aspects. In other words teachers' performance is pegged on the results of the national examinations regardless of what occasioned that performance (Ojiambo, 2009). Seemingly, teachers' efforts are reduced to naught; a fact that is authenticated by the assertion that great efforts employed by teachers towards positive formation of the students' attitudes, values and aspirations are largely ignored. The foregoing demoralizes many teachers. Recently, an evaluation of the effectiveness of school-based reward systems in promoting the performance of teachers in secondary 
schools in Kenya was carried out by Kituyi, Musau and Thinguri (2014). The authors established that every school prides in its ability to churn out students who have excelled academically at the end of an academic year.

\subsubsection{Secondary Schools in Nakuru Town East Sub-County}

Nakuru Town East Sub-County is one of the 11 sub-counties in Nakuru County, Kenya. The others include Nakuru Town West, Bahati, Subukia, Rongai, Kuresois South, Kuresoi North, Gilgil, Naivasha, Molo, and Njoro Sub- Counties. The Nakuru Town East Sub-County covers most of the Nakuru Town. It covers 74.30 square kilometers and has a population of 152,162 people. The sub-county has five wards namely Biashara, Kivumbini, Flamingo, Menengai and East Wards.It is home to 11 public secondary schools. This is due to the fact that the sub-county is densely populated. The predominant public secondary schools in the area include Nakuru High School and Nakuru Girls High School which enjoy the prestigious status of national schools (County Government of Nakuru, 2015). According to Kituyi et al (2014), the teachers' performance metrics are equated to the academic performance of students. The authors argue that the academic performance of students rests on the teachers' efforts; and as such boosting the morale of teachers is likely to result in enhanced academic performance. It is, therefore, important to examine the influence of job evaluation on the performance of teachers in public secondary schools.

\subsection{Statement of the Problem}

There has been glaring discrepancies between the salaries paid to teachers and those paid to other civil servants in terms of basic salary and allowances. The situation has been made worse by the recent increase of salaries for the workers of the TSC secretariat. Teachers who are employees of TSC have felt left out. The Salaries and Remuneration Commission (SRC), however, argues that teachers' salaries would only be reviewed after a job evaluation has been carried out. The teachers' unions have been using strikes to push for their cause. The strikes have no doubt impacted on performance of teachers and the education system as a whole.

There has been a lot of agitation both from the Kenyan government and the public for civil servants and state officials to sign performance contracts. The argument has all along stemmed from the view that when employees sign a contract for their performance, then that would be an apt metric against which their performance would be evaluated. In spite of the fact that performance contracts could facilitate objective evaluation and appraisal, teachers have been reluctant to sign them. On the face value, teachers are hitherto evaluated against the students' performance particularly in the national examinations. Yet, this metric is questionable given that students' performance is not entirely attributed to teachers' efforts; rather, other factors such as the school facilities, the caliber of students in the school and the parents' support among others play a fundamental role.

With the high population of teachers employed by the TSC (approximately 280,000), the need for job evaluation has not gained popularity. This is largely due to the argument that this initiative is relatively new within the teaching fraternity. It has also been faced with opposition from the teachers' unions. Job evaluation amongst teachers is very important given that its implications touch on teachers themselves, students, and other interested parties to the secondary schools. It is, thus crucial to determine how job evaluation impacts on performance of teachers in the aforementioned schools. With this knowledge the relevant policy makers will be on a vantage position of formulating strategies that if and when implemented will enhance the performance of teachers in these schools. It is against this backdrop that this study is being conducted.

\subsection{Purpose and Objective of the Study}

The purpose of this study was to examine the influence of various methods of job evaluation on teachers' performance in public secondary schools in Nakuru East Sub-County.

\subsection{Research Hypothesis}

$\mathbf{H}_{01}: \mu_{1}=\mu_{1}$ : The relationship between various methods of job evaluation and teachers' performance in public secondary schools in Nakuru East Sub-County is not statistically significant.

\subsection{LITERATURE REVIEW}

\subsection{Theoretical Framework}

In this part, theories that touch on job evaluation and performance are reviewed and discussed in the context of public secondary school teachers. In particular, the balanced scorecard and Vroom's expectancy theory are reviewed.

\subsubsection{Balanced Scorecard}

Organizations and institutions have diverse stakeholders with vested interests. As such, stakeholder models have all along been used in strategic thinking in these entities. Since 1990's, however, the stakeholder model has been translated into a balanced scorecard (Kaplan \& Norton, 1993; Ulrich, 1997). It is asserted that human resource (HR) issues are being woven around a balanced scorecard. The balanced scored is founded on the logic that in order for an entity to be considered success, it must satisfy the requirements of three major stakeholders who are investors, customers, and employees. Interpretatively, investors are interested in financial performance of the organization which is measured variously which, nevertheless, must entail economic profitability, market value, and cash flow. 
Moreover, the balanced scorecard is founded on four pillars; otherwise referred to as perspectives. These pillars include financial, customer, internal business process, and learning and growth. The four perspectives enable translation of visions and strategy. The aforesaid pillars are the drivers for creating long-term shareholder value. Regarding the first pillar, the question is how an organization should appear to its shareholders in order to succeed financially. On the perspective of internal business processes, the firm adopts those processes that would enable it to satisfy its shareholders and customers. Regarding the third pillar, the organization needs to understand how it should appear to its customers in order to achieve its vision. Lastly, the fourth pillar emphasizes on how an organization will sustain its ability to change and improve in order to achieve its vision (Kaplan, 2010).In the context of public secondary schools, the four perspectives of the balanced scorecard are applicable in that these institutions require financial resources for them to operate; it has customers in form of students; has internal processes and indeed, learning and growth in different spheres including academic performance.

Customers who use the organization's products (goods or services) are interested in quality and service of what is being offered. Such may include market share, customer commitment, customer retention, and other customer-focused issues. Thirdly, the organization's employees demand that the firm provides a healthy working environment in terms of employee and organizational actions. In the context of public secondary schools, the business scorecard is relevant in that a school has investors who are parents, guardians, government and other financiers who demand for proper utilization of financial resources they invest in the school.

Customers are students who are interested in being offered quality education as reflected in excellent academic performance. Lastly, employees include teachers and subordinate staff whose interest is in working in a school that is not oppressive; but one that promotes their performance and growth. According to Ulrich (1997), measuring employees has proven to be a rather difficult task. The author notes that employee measures are usually less accepted and less rigorous compared to customer and investor measures. In addition, Kaplan and Norton (2001) asserted that the balanced scorecard is one of the most widely employed models of measuring performance. It is explicitly justified as a means of developing causal models or strategy maps. Yet against this backdrop, it is revealed that democratic, participatory and inclusive performance appraisal practices such as the balanced score card are either minimally used or not used at all (Asiago\&Gathii, 2014).

The use of the balanced scorecard would facilitate objective and optimal appraisal of teachers' performance in secondary schools. This is due to the fact that metrics are participatory and inclusive and devoid of bias.

\subsubsection{Vroom's Expectancy Theory}

The Vroom's theory of expectancy was invented by Vroom in 1964. It outlines how effort, performance and rewards influence both individual and organizational performance. It is an example of a motivational theory. Vroom's theory is founded on the premise that an individual's behaviour is formed not on objective reality but rather on their subjective perception of that reality. Interpretatively, the theory relates how an individual perceives the relationships between efforts, performance and rewards (Vroom, 1968). The foregoing is linked to three factors which are expectancy, instrumentality and valence. Expectancy describes the extent of an individual's perception or belief that a given act will produce outcome instrumentality is the extent to which an individual perceives the effective performance will result in desired rewards; and valence illustrates the strength of the belief that attractive rewards are potentially available (Karuntimi\&Tarus, 2014). In the case of public secondary schools' teachers, teachers expect to be rewarded for their efforts; a fact that if effected would very likely impact positively on their performance.

\subsection{Job Evaluation Methods and Performance of Teachers}

Job evaluation aims at ensuring that there is high quality of the job. It is argued that job evaluation is a convenient way of referring to a systematic and impartial pricing of jobs. It is accomplished by thorough comprehensive job analysis. In other words, job evaluation is a study of relative worth of descriptive job characteristics culminating in a standardization of base rates and the establishment of a rate structure (Acas, 2005). There are four major methods of job evaluation which include ranking method, classification method, point factor rating method, and factor comparison method. Studies indicate that job evaluation is more common in the public sector than in the private industry (CIPD, 2004; CIPD, 2005). One of theCPD's annual reward surveys established that on average, almost 46 per cent of organizations used job evaluation to determine salary ranges in 2004 down from 48 per cent of firms in the preceding year(Suff\& Reilly, 2006).

Quality of a job is associated with how effectively and efficiently a given job is performed. Top-notch employees are very likely to carry out quality jobs in their respect departments and place of work. Aspinwall, Sampaio and Rodriguez (2005) conducted a study on performance measurement and quality tools in Portuguese small and medium enterprises (SMEs). They noted that employee performance in any organization is reflected by the effectiveness and efficiency with which goals and objectives are achieved. In the same light, Baldwin (2008) noted that excellent employee performance implies that the employee will conduct their duties efficiently and effectively to meet preset job objectives.

Time is a very crucial aspect in evaluating a given job. Mintzberg (1994) identified a number of factors that may account for difficulties with performance measures. Underestimating the length of time it takes for major changes is one of the causes for the aforesaid challenges. As asserted by Grober et al. (2006) induction period is dependent on the length of time required by a new employee to become effective on a certain job and also to learn and understand the involved activities. Interpretatively, time taken in a given job is one of the parameters of job evaluation. According to Hansson (2008), the measurement on human capital is closely linked to education-related factors such as time invested in education. 
Another way of enhancing the job quality is proper induction or orientation. Induction encapsulates the process of initiating new employees into an organization and acquainting them with the details and requirements of the job (Grober, Warnich, Carrell, Elbert \& Hatfield, 2006). The newly recruited employees are orientated on the expectations of their jobs in light of its contribution to the overall organization's success. They are also taken through how their job performance would impact on the society at large (Gomez-Mejia, Balkin\&Cardy, 2012). In addition to harnessing employees' skills, effective induction process enables optimum utilization of human resources in an organization which results in realization of both individual and organizational goals (Indradevi, 2010). More so, effective induction enhances confidence and performance of employees.

In addition, Omolo (2010) surveyed the dynamics and trends of employment in Kenya. The author sought to understand whether the employment status in Kenya is all about mass employment or quality jobs. It is pointed out that regardless of the employment creation intervention; questions still abound as to whether developing and labour surplus economies such as Kenya ought to prioritize fixing employment in terms of quantity then address quality, or that both quantity and quality of jobs should move in tandem. It is lamented that several employment targeted policy interventions pursued in Kenya have seemed to grant credence to having a quick fix in employment in terms of numbers with very scanty emphasis on the quality of the jobs. Omolo insists that in as much as possible quality of jobs should be a prerogative. It is further noted that the country faces many problems linked to quality of its workforce. The quality of the Kenyan workforce, it is posited, has received significant mention given the continued commitment of the government and other players within the labour and employment sector in order to promote labour productivity as a wage compensable factor.

\subsubsection{Teachers' Performance}

In Omolo's (2010) study on the dynamics and trends of employment in Kenya, it is noted that, over the years, there has been many policy blueprints on measures of creating employment in the country. More so, it has been noted that a lot of focus has been on employment policy formulation and legislation in Kenya with little and non-matching emphasis on policy implementation, monitoring, evaluation, and learning. A study on the experiences of teachers' appraisal practices in public secondary schools in Nairobi (Odhiambo, 2003) revealed that teachers perceived the performance appraisal negatively. In addition,Richu's (2007) study on perceptions of teachers on performance appraisal in public secondary schools in Nakuru district found that teachers viewed performance appraisal negatively.

While analyzing the teachers' perceptions of performance appraisal practices in public secondary schools in Limuru District, Kenya, Asiago and Gathii (2014)acknowledged that the evaluation of employees' present and past performance against standards set by respective organizations is important to the achievement of the organizational goals. The study further indicated that appraisal of teachers which encapsulates their evaluation is not an easy task in the context of public secondary schools. Indeed, the authors noted that most school heads had no training on how to appraise teachers.It is complained that the Kenyan education system tends to overlook the affective domain of the curriculum and instead acknowledges the cognitive aspects. In other words teachers' performance is pegged on the results of the national examinations regardless of what occasioned that performance (Ojiambo, 2009).

\subsection{Conceptual Framework}

A conceptual framework outlines the hypothetical relationship between the study variables. In particular, it illustrates how each of the independent variable affects the dependent variable as shown in Figure 1.

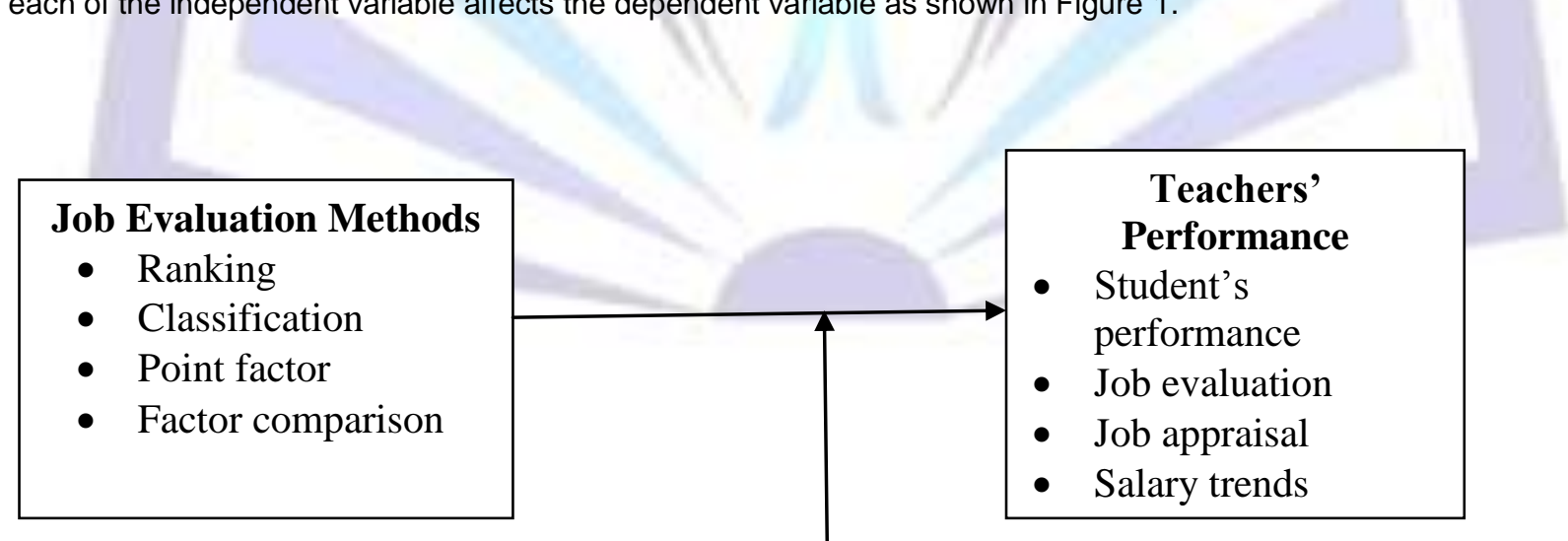

Independent Variable

Dependent Variable

TSC Act

Intervening Variable 


\subsection{RESEARCH METHODOLOGY}

\subsection{Research Design}

This is the roadmap of conducting the research study. The current study adopted a descriptive research design since it sought to analyze the views of the teaching staff in public secondary schools in Nakuru Town East Sub-County regarding job evaluation and their performance. As Kothari (2004) stated, descriptive study seeks to answer what kind of questions as exemplified by this study which examined"what is the effect of job evaluation on teachers' performance?"In particular, a survey method was adopted since the target population cut across teachers from all public schools in the aforementioned sub-county. The study basically employedquantitive approach which is measurable and as such it was possible to assess the influence of job evaluation methods on teachers' performance. The study mainly relied on primary data obtained from the sampled teachers.

\subsection{Sampling Frame}

A sampling frame describes an exhaustive list of individuals from which a sample of respondents is drawn. In this case, therefore, the 283 teachers constituted the sampling frame. Table 1 illustrates the sampling frame.

\section{Table 1: Sampling Frame}

\begin{tabular}{rlr}
\hline \multicolumn{2}{l}{ Name of Secondary School } & Number of Teachers \\
\hline i. & Menengai Hill Secondary & 19 \\
ii. & Menengai High school & 34 \\
iii. $\quad$ Moi Secondary School & 23 \\
iv. $\quad$ Nakuru High School & 41 \\
v. $\quad$ Nakuru Girls High & 36 \\
vi. $\quad$ Lanet Secondary School & 25 \\
vii. $\quad$ Crater View Secondary & 19 \\
viii. & NATEWA Secondary School & 18 \\
ix. $\quad$ Upperhill Mixed School & 26 \\
x. $\quad$ Nairobi Road Secondary School & 17 \\
xi. $\quad$ Hillcrest Secondary School & 25 \\
\hline
\end{tabular}

\subsection{Sample Size}

The sample size was calculated using the Nassiuma (2000) formula as outlined hereunder.

$$
\begin{aligned}
n=\frac{N C^{2}}{C^{2}+(N-1) e^{2}} & \text { Where } \\
& \mathrm{n}=\text { sample size; } \\
& \mathrm{N}=\text { population size; } \\
& \mathrm{C}=\text { coefficient of variation }(0.5) \\
& e=\text { error margin }(0.05)
\end{aligned}
$$

Calculating the sample size

$$
\begin{aligned}
& \mathrm{n}=\frac{283 \times 0.5^{2}}{\times 0.5^{2}+(283-1) 0.05^{2}} \\
& \mathrm{n}=74.08 \\
& \mathrm{n}=75 \text { respondents }
\end{aligned}
$$

\subsection{Data Processing and Analysis}

The collected questionnaires were verified to ensure that only the sets of questionnaires filled according to the expectations were used in the study. Thiswas followed by coding and entry of the raw data into the Statistical Package for 
Social Sciences (SPSS) version 21 software. The entered data then underwent both descriptive and inferential analyses. The SPSS was used to aid in the analyses. Descriptive analysis encapsulated frequency and percentage distributions specifically of the demographic data. More so, it included means as a measure of central tendencies and standard deviations as a measure of variation. On the other hand, inferential analysis whose intent will be to draw conclusions regarding job evaluation and teachers' performance will be in form of both Pearson's correlation coefficient and regression analysis. The study findings will be presented in form of tables that will capture summary statistics.

\subsection{Results and Findings}

\subsubsection{Job Evaluation Methods}

The study analyzed the views of the respondents regarding job evaluation methods as a proxy of job evaluation. Table 4.5 outlines the repondents' views regarding the construct

Table 2: Descriptive Statistics for Job Evaluation Methods

\begin{tabular}{|c|c|c|c|c|c|c|}
\hline & & $n$ & Min & Max & Mean & Std. Dev \\
\hline i. & Public secondary schools conduct job evaluation & 48 & 1 & 5 & 2.71 & 1.368 \\
\hline ii. & Ranking method is used to evaluate teachers & 48 & 1 & 5 & 3.79 & 1.543 \\
\hline iii. & Classification method is used to evaluate teachers & 48 & 1 & 5 & 3.83 & 1.374 \\
\hline iv. & Point factor rating is used to evaluate teachers & 48 & 1 & 5 & 3.46 & 1.320 \\
\hline v. & Factor comparison method is used to evaluate teachers & 48 & 1 & 5 & 3.50 & 1.353 \\
\hline vi. & Appropriate job evaluation method enhances job quality & 48 & 1 & 5 & 4.02 & 1.176 \\
\hline vii. & $\begin{array}{l}\text { Evaluation methods are the same across all employees in our } \\
\text { school }\end{array}$ & 48 & 1 & 5 & 3.29 & 1.557 \\
\hline
\end{tabular}

It was discovered that respondents were in agreement (mean $\approx 4.00)$ with the views ranking method was used to evaluate teachers;classification method was used to evaluate teachers;factor comparison method was used to evaluate teachers and that appropriate job evaluation method enhanced job quality. Respondents were however non-committal (mean $\approx$ 3.00 ) to the opinion that public secondary schools conducted job evaluation; point factor rating is used to evaluate teachers and that evaluation methods were the same across all employees in their school.

\subsection{Teachers Performance}

The study sought to assess respondents' take in regards to the teachers' performance. The aim was to assess the opinions of the respondents on the aforementioned subject. The respondents' views are presented in Table 3.

Table 3: Descriptive Statistics for Teachers' Performance

\begin{tabular}{|c|c|c|c|c|c|c|}
\hline & & $\mathbf{n}$ & Min & Max & Mean & Std. Dev \\
\hline i. & $\begin{array}{l}\text { Performance of public secondary school teachers is subject to different } \\
\text { factors }\end{array}$ & 48 & 1 & 5 & 4.35 & 1.021 \\
\hline ii. & Teachers perform differently & 48 & 1 & 5 & 4.13 & 1.044 \\
\hline iii. & $\begin{array}{l}\text { Performance of teachers is measured through student's academic } \\
\text { performance }\end{array}$ & 48 & 2 & 5 & 4.15 & 1.091 \\
\hline iv. & Job evaluation methods influences teachers performance & 48 & 1 & 5 & 4.10 & 1.134 \\
\hline v. & Job appraisal is vital in teachers' performance & 48 & 1 & 5 & 4.35 & .863 \\
\hline vi. & Performance of teachers is influenced by pay structures & 48 & 1 & 5 & 3.77 & 1.372 \\
\hline vii. & Job appraisal results are an indicator of teachers' performance & 48 & 1 & 5 & 4.33 & 1.310 \\
\hline
\end{tabular}

The study findings revealed that respondents were in agreement (mean $\approx 4.00$ ) to the argument that performance of public secondary school teachers was subject to different factors;teachers performed differently;performance of teachers was measured through student's academic performance;job evaluation methods influenced teachers' performance; job appraisal was vital in teachers' performance;performance of teachers was influenced by pay structures and that job appraisal results were an indicator of teachers' performance. 


\subsection{Relationship between Job Evaluation Methods and Teachers Performance}

The study aimed to determine the existence of the relationship and the extent of the relationship between job evaluation and teachers' performance. The results from the analysis are displayed in Table 4.

Table 4: Relationship between Job Evaluation and Teachers Performance

Teachers Performance

Job Evaluation Methods

Pearson Correlation

$.582^{\pi \times}$

Sig. (2-tailed)

.000

$\mathrm{n}$

48

${ }^{* *}$. Correlation is significant at the 0.01 level (2-tailed).

It was found that there exists a strong, positive and statistically significant relationship $(r=0.582 ; p<0.01)$ between job evaluation methods and teachers performance. This meant that job evaluation methods had a positive effect and largely affected performance of the teachers. It therefore implied that when teachers were evaluated by appropriate job evaluation methods, their quality of work was enhanced and therefore performance was equally enhanced. Appropriate job evaluation methods were therefore crucial for the performance of teachers. The findings agreed with Aspinwall et al.'s (2005) observations that the various methods of job evaluation are likely to influence the performance of the workforce particularly when done right.

\subsection{Summary of the Findings.}

\subsubsection{Job Evaluation Methods and Teachers Performance}

It was agreed that ranking, classification and factor comparison methods were used to evaluate teachers. It was also in agreement that appropriate job evaluation methods enhanced job quality. However, respondents were non-committal whether public secondary schools conducted job evaluation; point factor rating was used to evaluate teachers and that job evaluation methods were the same across all employees in their school. Further analysis indicated a strong, positive and statistically significant relationship $(r=0.582 ; p<0.01)$ between job evaluation and teachers performance. It was elucidated that teachers' performance was enhanced as a result of improved quality of work due to the use of appropriate job evaluation methods.

\subsubsection{Teachers' Performance}

It was in concurrence that performance of public secondary school teachers was subject to different factors and that teachers performed differently. In addition, theperformance of teachers was measured through student's academic performance andjob evaluation methods used influenced teachers' performance. I was further admitted that job appraisal was vital in teachers' performance;performance of teachers was influenced by pay structures and that job appraisal results were an indicator of teachers' performance.

\subsection{Conclusions of the Study}

The study concluded that ranking, classification and comparison factor were the methods used to evaluate teachers. Notably, it was further inferred that appropriate methods of job evaluation were critical in the enhancement of job quality and consequent teachers' performance.

\subsection{Recommendation}

This section outlines a number of recommendations in line with the study objectives and findings.

\subsubsection{Recommendation on Job Evaluation Methods}

The study recommended that appropriate job evaluation methods should be used and upheld since they are crucial in the quality of the teachers output.

\subsection{Suggestions for Further Studies}

The study suggests a number of themes to be further researched in Kenya. These studies include; the role of job appraisal on the performance of teachers in private secondary schools; A comparative study of the influence of job evaluation on performance of teachers in public and private secondary schools; assessment of job evaluation methods on performance lectures in institutions of higher learning.

\section{REFERENCES}

1. Asiago, D., \&Gathii, A. (2014). Teachers' perceptions of performance appraisal

2. practices in public secondary schools in Limuru District. International Journal of Education and Research, 2(4), 112. 
3. Dessler, G. (2008). Human Resource Management.(11 ${ }^{\text {th }}$ Ed.). New Jersey: Pearson

4. Education.

5. Gomez-Mejia, L.R., Balkin, D.B., \&Cardy, R.L. (2012).Managing Human Resources.

6. New York: Pearson Education, Inc.

7. Grobler, P., Warnich, S., Carrell, M.R., Elbert, N.F., \&Hatfiel, R.D. (2006).Human

8. Resource Management in South Africa .( $3^{\text {rd }}$ Ed.). London: Cengage Learning EMEA.

9. Hanson, B. (2008). OECD Measures on Human Capital and Potential Use in Educational

10. Accounts.Workshop on the Measurement of Human Capital. New York: Pearson Publishers.

11. Indradevi, R. (2010). Training for Most Capable Workforce, Advances in Management,

12. 3(12), 1-7.

13. Kaplan, R.S. (2010). Conceptual Foundations of the Balanced Scorecard. Working Paper 10-074

14. Karuntimi, L.K., \&Tarus, B. (2014). An assessment of the performance evaluation

15. system used to evaluate teachers in secondary schools in Meru Central District - Kenya. Academic Journal of Interdisciplinary Studies, 3(6), 199-204.

16. Kituyi, I., Musau, N., Thinguri, R. (2014). An evaluation of the effectiveness of school

17. based reward system in enhancing teacher performance in secondary schools in Kenya. International Journal of Education and Research, 2(4), 463-474.

18. Kothari, C. (2004). Research Methodology: Methods and Techniques. New Delhi:

19. New Age International Publishers..

20. Malongwe, C. (2005). Towards an effective self appraisal. Gaborone: Government

21. printers.

22. Mintzberg, H. (1994). The Rise and Fall of Strategic Planning. New York: Free Press.

23. Monyatsi, P., Steyn, T., \&Kamper, G. (2006). Teacher appraisal in Botswana secondary

24. schools: A critical analysis. South African Journal of Education, 26(2), 215-228. .

25. Odhiambo, G. D. (2003). Teacher Appraisal. The experience of Kenyan secondary

26. schools teachers, Journal Of Education Administration, 43(4), 402-416.

27. Omolo, J. (2010). The Dynamics and Trends of Employment in Kenya. Nairobi: Institute

28. of Economic Affairs.

29. Richu, A. (2007). A survey of Teachers Perception of Performance Appraisal Practices

30. in Public Secondary Schools in Nakuru District. Unpublished MBA Thesis, University of Nairobi.

31. Sousa, S. D., Aspinwall, E., Sampaio, P. A., \& Rodrigues, A. G. (2005). Performance

32. measurement and quality tools in Portuguese small and medium enterprises: Survey results. Total Quality Management,16(2), 277- 307.

33. Townley, B.,Cooper, D.J., \& Oakes, L. (2003). Performance Measures and the

34. Rationalization of Organizations. London: SAGE Publications

35. Ulrich, D. (1997). Measuring human resources: An overview of practice and a

36. prescription for results. Human Resource Management, 36(3), 303-320. 